\title{
Glyphosate commercial formulation effects on preoptic area and hypothalamus of Cardinal Neon Paracheirodon axelrodi (Characiformes: Characidae)
}

\author{
Camilo Riaño-Quintero ${ }^{1}$, Edwin Gómez-Ramírez ${ }^{1}$ and Hernán Hurtado-Giraldo ${ }^{2}$
}

In Colombia the use of glyphosate commercial formulations (Roundup ${ }^{\mathrm{TM}}$ ) for spraying have left deleterious effects on animals and humans. Much of this spraying takes place at the Orinoco basin, habitat of one of the most exported ornamental fish in Colombia, Cardinal neon. To evaluate the effect of Roundup Activo ${ }^{\mathrm{TM}}$ four experimental treatments were carried out with 0 $\mathrm{mg} / \mathrm{L}$ (T1), $0.1 \mathrm{mg} / \mathrm{L}$ (T2), $1 \mathrm{mg} / \mathrm{L}$ (T3) and $5 \mathrm{mg} / \mathrm{L}$ (T4) during 30 days of exposure. The fishes were processed for highresolution optical microscopy. The main finding of Roundup Activo ${ }^{\mathrm{TM}}$ exposure was an increase in mast cells number in brain blood vessels and some neuronal nuclei of the preoptic and posterior diencephalic areas, including hypothalamus. A correlation between concentrations and mast cells number was observed, with the largest mast cells number in T4 treatment. Mast cells presence is a stress benchmark, suggesting the beginning of allergic, inflammatory and apoptotic events. Presence of mast cells in these brain areas may lead to alterations on reproduction, visual and olfactory information integration among other processes. These alterations may result in diminished survival, affecting the conservation of this species in its natural habitat.

Keywords: Herbicide, Mastocyte-like cells, Ornamental fish, Survival.

En Colombia, el uso de formulaciones comerciales de glifosato (Roundup ${ }^{\mathrm{TM}}$ ) para la fumigación ha producido efectos nocivos en animales y humanos. Gran parte de esta fumigación se realiza en la cuenca del Orinoco, hábitat de uno de los peces ornamentales más exportados de Colombia, el Neón Cardenal. Para evaluar el efecto de Roundup Activo ${ }^{\mathrm{TM}}$ se realizó un experimento con cuatro tratamientos $0 \mathrm{mg} / \mathrm{L}$ (T1), $0,1 \mathrm{mg} / \mathrm{L}$ (T2), $1 \mathrm{mg} / \mathrm{L}$ (T3) y $5 \mathrm{mg} / \mathrm{L}$ (T4) durante 30 días. Los peces fueron procesados para microscopía óptica de alta resolución. El principal hallazgo fue el aumento del número de mastocitos en los vasos sanguíneos cerebrales y algunos núcleos neuronales del área preóptica y diencefálica posterior, incluido el hipotálamo. Identificamos una correlación entre las concentraciones y el número de mastocitos, que alcanzó su máximo en T4. La presencia de mastocitos evidencia estrés, promoviendo eventos alérgicos, inflamatorios y apoptóticos. La presencia de mastocitos en estas áreas del cerebro puede llevar a alteraciones en la reproducción e integración de la información visual y olfativa entre otros procesos. Estas alteraciones pueden resultar en una disminución de la supervivencia, afectando la conservación de esta especie en su hábitat natural.

Palabras clave: Herbicida, Mastocitos, Pez ornamental, Supervivencia.

\section{Introduction}

Glyphosate is an acidic compound used as a not specific herbicide. Its IUPAC name is N-(phosphonomethyl) glicine, and is commonly used as an isopropilamine salt with a surfactant. Polioxiethilen-amine (POEA) and Cosmoflux $411 \mathrm{~F}$ are the most common surfactants included in commercial formulations (Ramírez, Rondón, 2003). Glyphosate remanence time in water depends on sediment chemistry, staying up to 14 days after spraying, at a concentration of $0.6 \mathrm{mg} / \mathrm{kg}$ in sediment, and up to 400 days after aspersion in lentic water bodies. In general Roundup ${ }^{\mathrm{TM}}$ may stay in water one to three weeks (WHO, 1994). This herbicide in used in legal agriculture in order to control weeds, grain drying and spraying of transgenic crops. However, in Colombia, glyphosate has been also widely used for illegal crop spraying (Ramírez et al., 2008). In September 2015, Colombian government banned glyphosate for illegal crops spraying, but a 2014 United Nations Office on Drugs and Crime (UNODC) shows that illegal crop areas had increased on about $40 \%$ in Colombian Meta and Guaviare departments, Cardinal neon Paracheirodon axelrodi (Schultz, 1956)

\footnotetext{
${ }^{1}$ Grupo de ecotoxicologia, evolución, medio ambiente y conservación, Facultad de Ciencias Básicas, Universidad Militar Nueva Granada, km 2 vía Cajicá-Zipaquirá, Colombia. (CRQ) u0500743@unimilitar.edu.co, Ohttps://orcid.org/0000-0001-8375-5270 (corresponding author); (EGR) edwin.gomez@unimilitar.edu.co, Dhttps://orcid.org/0000-0002-6700-9603

${ }^{2}$ Laboratorio de neurociencias, Escuela de Medicina, Universidad de Santander, Calle 70 \# 55-210 Bucaramanga, Colombia. hurticos@ yahoo.com, Ohttps://orcid.org/0000-0003-1175-8872
} 
habitat; opening a discussion on glyphosate interdiction, pointing out to use continuous manual spraying, as a new illegal crops control alternative.

Studies on fish exposure to glyphosate and glyphosate commercial formulations have been made on sub lethal doses, imitating what is most probably found at natural ecosystems (Glusczak et al., 2007; Kreutz et al., 2011). According to Cattaneo et al. (2011), acetylcholinesterase (AChE) activity in Cyprinus carpio Linnaeus, 1758 brain is progressively reduced after a $96 \mathrm{~h}$ glyphosate treatment with 0.5 to $10 \mathrm{mg} / \mathrm{L}$ concentration. Sandrini et al. (2013) have shown a diminished (50\%) AChE activity associated to 1.165 $\mathrm{mg} / \mathrm{L}$ and $1.52 \mathrm{mg} / \mathrm{L}$ glyphosate exposure for Danio rerio (Hamilton, 1822) and $1.77 \mathrm{mg} / \mathrm{L}$ and $2.47 \mathrm{mg} / \mathrm{L}$ for Jenynsia lineata (Jenyns, 1842). Sinhorin et al. (2014) showed that siluriform fish Pseudoplatystoma sp. suffers from liver, brain and muscle oxidative stress after commercial glyphosate exposure at 2.25, 4.5, 7.5 and $15 \mathrm{mg} / \mathrm{L}$ concentrations. Hued et al. (2012) have reported that 5, 10, 20,35, 60 and $100 \mathrm{mg} / \mathrm{L}$ Roundup Max ${ }^{\mathrm{TM}}$ concentrations reduce clotting time, female courtship and coupling success in J. lineata exposed for 28 days. Mesnagea (2012) found that surfactant to be more toxic to fish that glyphosate, POEA exposed may lead to loss of cell membranes in human germinal, liver and placental cells at 1 to $3 \mathrm{mg} / \mathrm{L}$ concentration. Roundup ${ }^{\mathrm{TM}}$ levels up to $200 \mathrm{mg} / \mathrm{L}$ are reported to produce damage in fishes, while half surfactant concentrations are able to lead to erratic swimming, and behavioral alterations in Oncorhynchus mykiss (Walbaum, 1792) and Oreochromis spp. (Cox, 2000).

Paracheirodon axelrodi brain present olfactory bulbs (OB), telencephalic hemispheres (TH), optic lobes (OL), inferior lobes (IL), cerebellum (CE) and medulla oblongata (MO) (Obando et al., 2013). Fish preoptic area is located from mid telencephalic hemispheres to rostral hypothalamus. This area plays a role in processing retinal input to brain, control of oculomotor reflexes, regulation of circadian cycles, and control of reproduction (Butler, Hodos, 2005; Gaikwad et al., 2005; O'Connell et al., 2013). Posterior diencephalic area (PDR) including hypothalamus (HT) is found along optic and inferior lobes, and modulates reproduction, using GABA and dopamine neurons for integration of visual, taste and sensorial information (Cerdá-Reverter, Canosa, 2009; O'Connell et al., 2013).

For the above, in this article we want to identify the effect of a commercial presentation of glyphosate on some areas of the encephalon in order to generate data that allow us to support protection plans for conservation of this species and additionally inform about the consequences of the excessive use of glyphosate.

\section{Material and Methods}

Experimental design. Fishes from 2 to $2.8 \mathrm{~cm}$ total length were kept in $40 \mathrm{~L}$ aquaria for 30 days with low light incidence. Four different treatments were used, T1: $0 \mathrm{mg} / \mathrm{L}, \mathrm{T} 2: 0.1$ $\mathrm{mg} / \mathrm{L}$, T3: $1.0 \mathrm{mg} / \mathrm{L}$, and T4: $5.0 \mathrm{mg} / \mathrm{L}$, with four replicas/ treatment, thirty fishes/aquarium. These concentrations were adjusted based on the active ingredient of the commercial product. Fishes were kept in semi static systems with $\mathrm{pH}$ of 6.0 to 6.5 , and temperature of 25 to $26^{\circ} \mathrm{C}$. Animals were feed with Tetracolor ${ }^{\circledR} 47.5 \%$ crude protein, at $6 \%$ of total biomass, three times/day at 8:00, 12:00 and 16:00 hours (Anjos, Anjos, 2006). The individuals were obtained in stores specializing in ornamental aquatic species. The species is identified in the Instituto de Investigación de Recursos Biológicos Alexander von Humboldt, Colleción de Peces, Villa de Leyva, Colombia with reference code IAvH-P 10312.

Tissue sampling and processing. Fishes were euthanized by benzocaíne $(0.5 \mathrm{~g} / \mathrm{L})$ treatment, followed by spinal cord section at cervical level, according to ethical fish management procedures (AVMA, 2013). After a 30 days exposure, six animals per aquarium were euthanized. Three of them were used for high-resolution optical microscopy, the other three were kept for future ultrastructural studies. Brains were dissected and fixed in a modified Karnovsky solution (2\% formaldehyde and $2.5 \%$ glutaraldehyde) in phosphate buffer $\mathrm{pH} 7.2$ for two hours. Tissues were rinsed three times with phosphate buffer, followed by postfixation with $2 \%$ osmium tetroxide in phosphate buffer. Brain were rinsed again with buffer and dehydrated with ethanol 70\%, 90\%, 95\% and $100 \%$. After dehydration, tissues were embedded in Poly/ Bed ${ }^{\circledR 812-p r o p y l e n ~ o x i d e ~ 1: 2 ~ a n d ~ 1: 1, ~ w i t h ~ a ~ f i n a l ~} 100 \%$ Poli/Bed®812. Samples were polymerized at $60^{\circ} \mathrm{C}$ (Obando et al., 2013; Rincón et al., 2017). Sections were obtained with Microm Slee Cut 40650 rotatory microtome and stained with toluidine blue (Obando et al., 2013; Rincón et al., 2017). Photographs were examined in the microscope Zeiss Axio Scope A1 coupled to a Zeiss Axiocam ICM 1 camera. Diagrams of cuts were made using Adobe Photoshop CC 2015 software. A description of mastocyte distribution and number per field was made using these digital images. The preoptic area $( \pm 72 \mu \mathrm{m})$ and the posterior diencephalic region $( \pm 516 \mu \mathrm{m})$ were analyzed (Obando et al., 2013). The cell count MC was performed by direct counting supported by the analysis of images made in the ImageJ software (https:// imagej.nih.gov/ij/) with a space margin of $12 \mu \mathrm{m}$ between each cut analyzed to avoid repeating any cell previously counted. In total, $\pm 588 \mu \mathrm{m}$ were analyzed per replica.

Statistics analysis. A Shapiro-Wilk test was used to evaluate normality. ANOVA tests were used for detection of significant differences among treatments at a $p<0.05$ level with R 3.2.3 software.

\section{Results}

Preoptic Area (AP). The cuts were made in two areas of the brain (preoptic area and posterior diencephalic region) (Fig. 1). $\mathrm{MC}$ cells were observed at $\mathrm{T} 2, \mathrm{~T} 3$ and $\mathrm{T} 4$, associate with blood vessels adjacent to brain tissue (Figs. 2-3). However, some MC cells were found within brain parenchyma in 
some neuronal nuclei, like mid area of dorsal telencephalon (MD), lateral area of dorsal telencephalon (LD) and anterior parvocellular preoptic nucleus $(\mathrm{PPa})$.
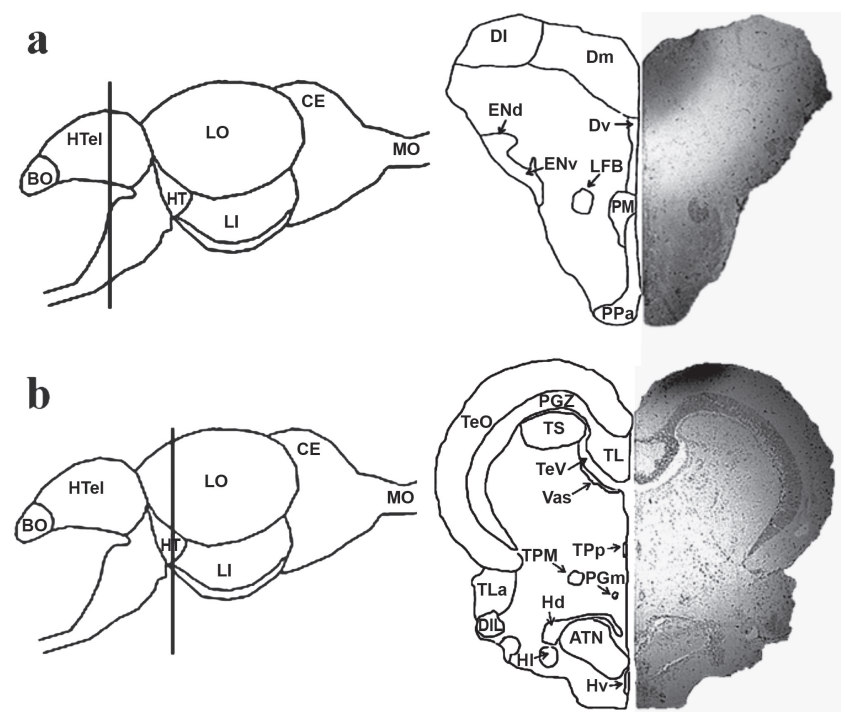

Fig. 1. Cross-section of preoptic area (AP) and posterior diencephalic region (PDR) of Paracheirodon axelrodi showing its different neuronal nuclei. a. Panoramic view of AP showing different neuronal nuclei. b. Panoramic view of PDR, including HT neuronal nuclei. Technique: high resolution optical microscopy (HROM) Bar $100 \mu \mathrm{m}$.

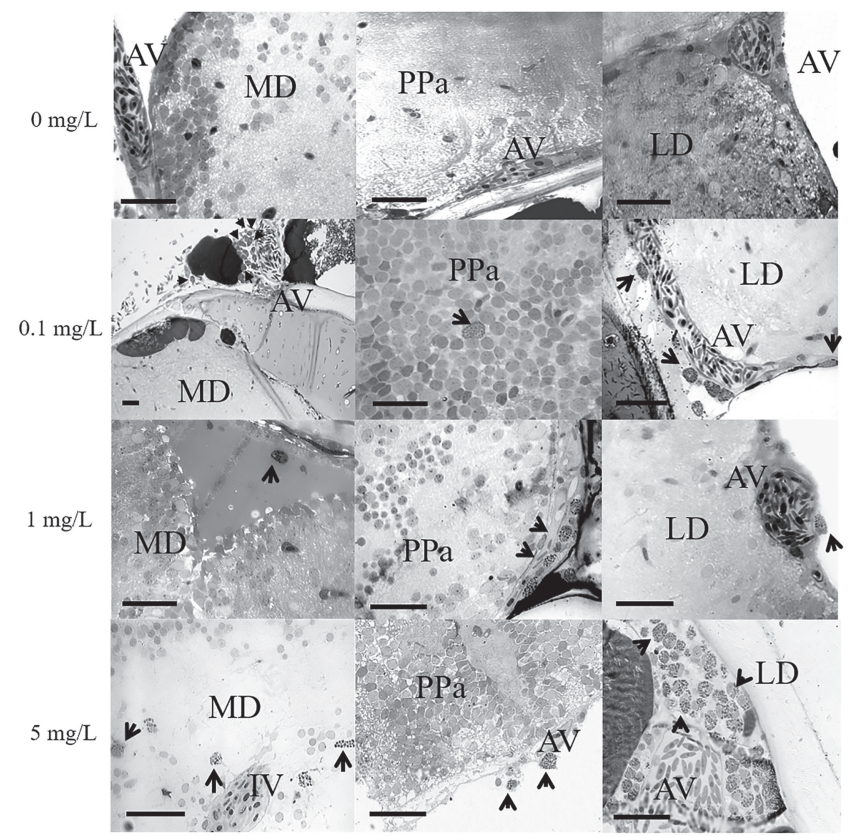

Fig. 2. Cross-sections of preoptic area (AP) of Paracheirodon axelrodi for different treatments with Roundup $\mathrm{Activo}^{\mathrm{TM}}$. MC cells are present at different AP nuclei in all treatments. Mid dorsal telencephalic nucleus (MD). Anterior preoptic parvocelular nucleus (PPa). Lateral dorsal telencephalic nucleus (LD). Adjacent blood vessels (AV) and internal blood vessels (IV) are shown. MC cells are shown by black arrows. Technique: high resolution optical microscopy (HROM). Bar $25 \mu \mathrm{m}$.
Posterior diencephalic area and hypothalamus. MC cells distribution was similar for T2, T3 and T4 treatments (Fig. 3). These cells were observed at Optic Tectum (TeO), Torus semicircularis (TS), Grey periventricular area of optic tectum (PGZ), Torus lateralis (TLa), diencephalic ventricle (DiV) and ventral area periventricular hypothalamus (Hv). The MC cells were observed in blood vessels adjacent to PDR. However some MC cells were also found within cerebral parenchyma. No signs of MC degranulation were observed.

Figure 4 shows significant statistical differences in the number of MC cells for the different treatments. These results show that the number of MC cells is directly proportional to the increase in the concentration of Active Roundup ${ }^{\mathrm{TM}}$ in the treatments. For the treatments with 1 and $5 \mathrm{mg} / \mathrm{L}$ of Roundup Activo ${ }^{\mathrm{TM}} \mathrm{MC}$ cells were found in some neuronal nuclei of both the preoptic area and the posterior diencephalic region, being more abundant in mid area of dorsal telencephalum (MD), anterior parvocellular preoptic nucleus (PPa), periventricular gray area of optic tectum (PGZ), optic tectum (TeO) and Torus lateralis (TLa) (Tab. 1). The MCs cells were also found in the blood vessels adjacent to the brain, treatments with 1 and $5 \mathrm{mg} / \mathrm{L}$ of Roundup Activo ${ }^{\mathrm{TM}}$ were the ones with the highest number of these cells (Tab. 2).

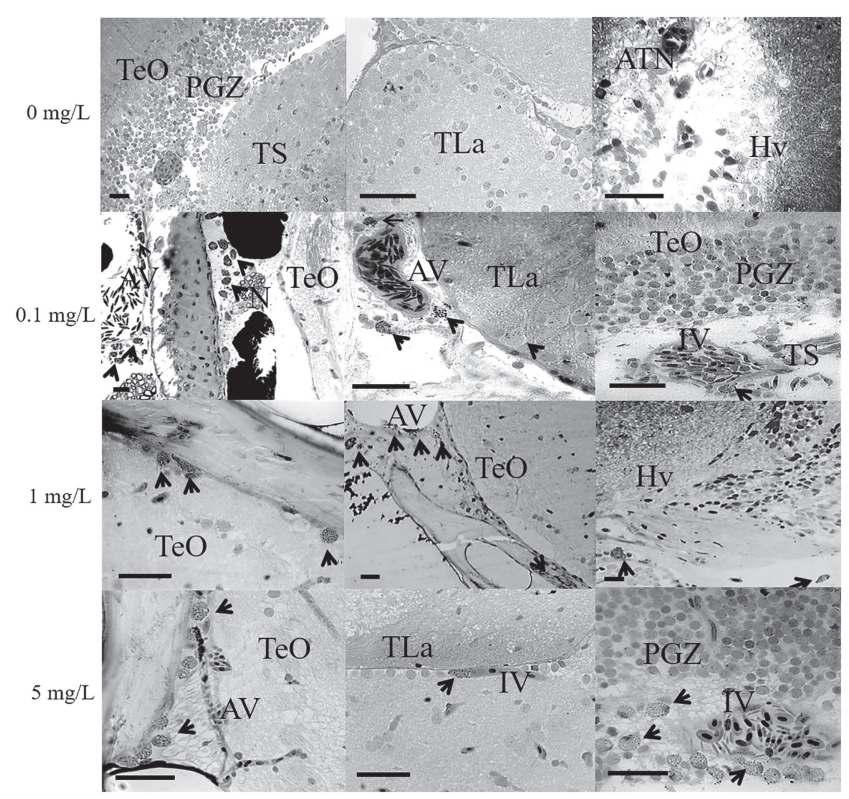

Fig. 3. Cross-sections of posterior diencephalic region (PDR) of Paracheirodon axelrodi for different treatments with Roundup Activo ${ }^{\mathrm{TM}}$. MC cells were found at different neuronal nuclei of posterior diencephalic area (PDR) in all treatments. Optic Tectum $(\mathrm{TeO})$, gray periventricular area of optic tectum (PGZ), Torus semicircularis (TS), Torus lateralis (TLa), Hypothalamus with ventral are of periventricular hypothalamus (Hv) and anterior tuberal nucleus (ATN). Adjacent blood vessels (AV), internal blood vessels (IV), nerve $(\mathrm{N})$. MC cells are shown by black arrows. Technique: high resolution optical microscopy (HROM). Bar $25 \mu \mathrm{m}$. 


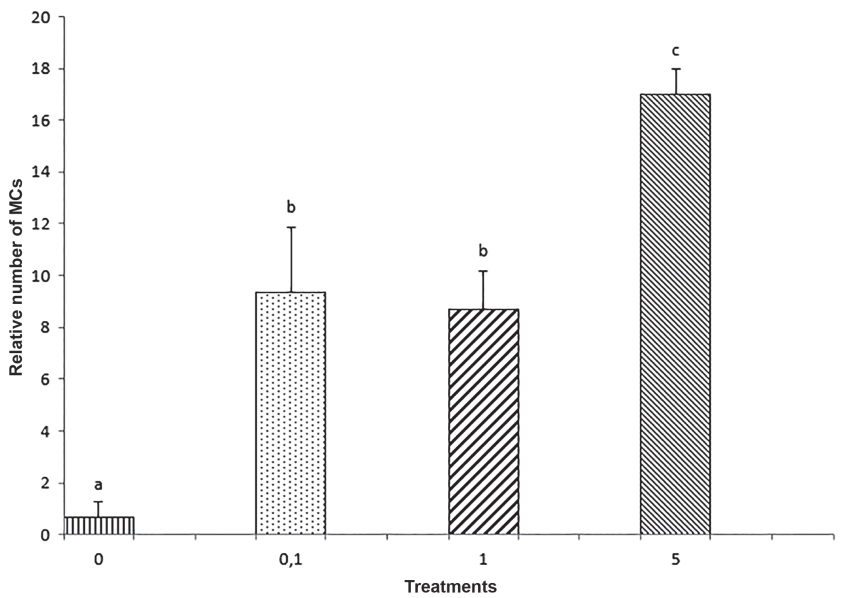

Fig. 4. Number of AP and PDR parenchyma MC cells found for each one of Roundup Activo ${ }^{\mathrm{TM}}$ treatments. Each value represents mean $\pm \mathrm{SD}$. Different letters correspond to significant differences $(\mathrm{P}<0.05$ values $)$. The treatments are in units of $\mathrm{mg} / \mathrm{L}$. $\mathrm{N}=3$.

No morphological alteration of AP and HT was observed after Roundup Activo ${ }^{\mathrm{TM}}$ treatments. AP, PDR and HT staining and distribution are similar to other teleost species (Rincón et al., 2017).

\section{Discussion}

Preoptic area and hyphothalamus present several neuronal nuclei as described for $P$. axelrodi (Obando et al., 2013; Rincón et al., 2017), similar to other teleost species like D. rerio and Carassius auratus (Linnaeus, 1758) (Fryer, Maler, 1981; Wullimann et al., 1996). Neurons form preoptic area usually have round nuclei, scarce cytoplasm. Neuronal size and toluidine blue staining present variations: anterior parvocelular preoptic (PPa) neurons exhibit very staining than neurons from magnocelular preoptic (PM) neurons. However, PPa neurons are smaller in size than PM neurons (Rincón et al., 2017).

At posterior diencephalic area, neurons form ventral hypothalamic (Hv) area, located around diencephalic ventricle (Div) do show round and strongly stained nuclei, with scarce cytoplasm. Optic Tectum $(\mathrm{TeO})$ neurons have weakly stained nuclei, while at grey periventricular area from optic tectum (PGZ) neurons around Torus Semicircularis (TS) have with scarce cytoplasm, but strongly stained AP and HT do have a lot of parenchymal and peripheral blood vessels, the latter being of larger size (Rincón et al., 2017).

Histopathological alterations. Appearance of MC cells after T1, T2 and T3 treatments was the main effect observed on preoptic and posterior diencephalic areas, including hypothalamus. As MC cell granules contain heparin sulfate, these cells can be visualized with a metachromatic stain like toluidine blue, leading to a deep purple staining (Reite, Evensen, 2006; Nelissen et al., 2013).
Tab. 1. Number of MC cells of Paracheirodon axelrodi at some preoptic area (AP) neuronal nuclei, posterior diencephalic area (PDR) at different Roundup Activo ${ }^{\mathrm{TM}}$ concentration. Each value does represent mean $\pm \mathrm{SD}$. Different letters correspond to significantly differences between treatments $(\mathrm{P}<0.05)$. Nuclei: $\mathrm{LD}$ : lateral area of dorsal telencephalum, MD: mid area of dorsal telencephalum, PPa: anterior parvocelular preoptic nucleus, TeO: optic tectum, TS: Torus semicircularis, PGZ: periventricualr grey area of optic tectum, TLa: Torus lateralis, DiV: diencephalic ventricle, Hv: periventricular hypothalamus of ventral area.

\begin{tabular}{|c|c|c|c|c|c|}
\hline & Nucleus & $0 \mathrm{mg} / \mathrm{L}$ & $0.1 \mathrm{mg} / \mathrm{L}$ & $1 \mathrm{mg} / \mathrm{L}$ & $5 \mathrm{mg} / \mathrm{L}$ \\
\hline \multirow{3}{*}{ 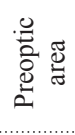 } & LD & $0.67 \pm 0.58^{a}$ & $1 \pm 0^{a}$ & $1 \pm 1^{\mathrm{a}}$ & $1.33 \pm 0.57^{\mathrm{a}}$ \\
\hline & MD & $0^{\text {a }}$ & $0.67 \pm 0.58 \mathrm{ab}$ & $1 \pm 0^{\mathrm{c}}$ & $2.67 \pm 0.58^{d}$ \\
\hline & $\mathrm{PPa}$ & $0^{\text {a }}$ & $2 \pm 1.73 \mathrm{ab}$ & $3.3 \pm 0.58^{b}$ & $2 \pm 1^{a b}$ \\
\hline \multirow{6}{*}{ 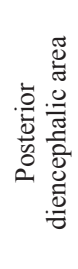 } & $\mathrm{TeO}$ & $0^{a}$ & $2.33 \pm 0.58^{b}$ & $2.33 \pm 0.58^{b}$ & $3.3 \pm 0.6^{\mathrm{b}}$ \\
\hline & TS & $0^{\text {a }}$ & $1 \pm 0^{\mathrm{b}}$ & $0^{\text {a }}$ & $0^{\text {a }}$ \\
\hline & PGZ & $0^{\text {a }}$ & $1 \pm 0^{\mathrm{b}}$ & 0 ac & $5.33 \pm 0.58^{d}$ \\
\hline & TLa & $0^{\text {a }}$ & $1.33 \pm 0.58 \mathrm{ab}$ & $0^{\text {a }}$ & $2.33 \pm 1.53^{b}$ \\
\hline & Div & $0^{\text {a }}$ & $0^{\text {a }}$ & $0.7 \pm 0.6^{\mathrm{a}}$ & $0^{\mathrm{a}}$ \\
\hline & $\mathrm{Hv}$ & $0^{\text {a }}$ & $0^{\text {a }}$ & $0.33 \pm 0.58^{a}$ & $0^{\mathrm{a}}$ \\
\hline
\end{tabular}

Tab. 2. Qualitative assessment of MC abundance in adjacent blood vessel at Preoptic and posterior diencephalic (including hypothalamus) areas of Paracheirodon axelrodi. 0: Absence of MCs, 1 to 10 cells (+), 11 to 40 cells (++), more than 40 cells $(+++)$.

\begin{tabular}{|c|c|c|c|c|c|}
\hline & Blood vessel & $0 \mathrm{mg} / \mathrm{L}$ & $0.1 \mathrm{mg} / \mathrm{L}$ & $1 \mathrm{mg} / \mathrm{L}$ & $5 \mathrm{mg} / \mathrm{L}$ \\
\hline \multirow{2}{*}{ 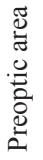 } & $\begin{array}{l}\text { Adjacent to left lateral } \\
\text { dorsal telencephalon }\end{array}$ & + & + & ++ & ++ \\
\hline & $\begin{array}{l}\text { Adjacent to right lateral } \\
\text { dorsal telencephalon }\end{array}$ & + & + & + & ++ \\
\hline \multirow{4}{*}{ 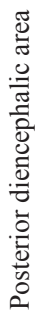 } & $\begin{array}{l}\text { Adjacent to left optic } \\
\text { tectum }\end{array}$ & 0 & + & ++ & +++ \\
\hline & $\begin{array}{l}\text { Adjacent to right optic } \\
\text { tectum }\end{array}$ & 0 & + & + & +++ \\
\hline & $\begin{array}{l}\text { Adjacent to left torus } \\
\text { lateralis }\end{array}$ & + & 0 & 0 & 0 \\
\hline & $\begin{array}{l}\text { Adjacent right torus } \\
\text { lateralis }\end{array}$ & + & 0 & 0 & 0 \\
\hline
\end{tabular}

The MC cells or granular eosinophilic cells (EGCs) are homologous to mammal mast cells, where they play a role in innate and adaptative immune response (Nelissen et al., 2013), promoting an inflammatory reaction triggered by an allergenic or toxic agent, stress or trauma (Reite, Evensen, 2006), mediated by the release of pro-inflammatory and vasoactive substances like histamine, serotonin, cytokinins and proteolytic enzymes (Dezfuli et al., 2000; Theoharides, Cochran, 2004). These cells also present substances like nerve growth factor (NGF), acid and alkaline phosphatases, antimicrobials (piscidins), tumor necrosis factor (TNF) among others (Theoharides, Cochran, 2004; Wilhelm et al., 2005; Mulero et al., 2007). 
Based on MC cells role in immunity in teleost fishes, our results may indicate that the exposure to Roundup Activo ${ }^{\mathrm{TM}}$ is related to an increase in $\mathrm{MC}$ cells due to a stress reaction, leading to the activation of $P$. axelrodi immune system. This interpretation is supported by the observation of a MC cells infiltration in peripheral brain blood vessels and in some neuronal nuclei like AP and PDR (Figs. 2-3), specifically at mid area of dorsal telencephalon (MD), anterior preoptic parvocelular nucleus $(\mathrm{PPa})$ and lateral area of dorsal telencephalon (LD).

Statistical analysis showed significant differences $(\mathrm{P}<0.05)$ between control (T1) and T3 and T4 for MD, while at $\mathrm{PPa}$, the larger number of MC cells was observed after $\mathrm{T} 3$ treatment. However, no significant differences were detected at LD between control (T1) and exposed animals (Tab. 1). Lack of effect after exposure was also observed at $\mathrm{TeO}$, but at PGZ, with a 5 to 8 range of MC cells, T4 treatment exhibited a larger number of cells. At TS and TLa, even with a low number of $\mathrm{MC}$ cells, significant differences were found between control and T3 and T4. For all other neuronal nuclei no statistical differences were observed (Tab. 2).

The presence and number of MC cells is directly related to glyphosate concentration in Roundup Activo ${ }^{\mathrm{TM}}$, for example the $\mathrm{MC}$ cells number in brain parenchyma was higher in T4 than $\mathrm{T} 1(17 \pm 1$ and $0.66 \pm 0.57)$. Finally, no significant differences were detected between T2 and T3 treatments (Fig. 4). These results could be explained as a Roundup Activo ${ }^{\mathrm{TM}}$ triggered activation of immune system in fishes like P. axelrodi in spite of the low concentrations used. Our results also increase the possibility of even greater effects, such as increased number of mast cells, degranulation, decreased $\mathrm{AChE}$ activity, increased vascular permeability, acute inflammation and cell death (Reite, Evensen, 2006; Gómez, 2013; Meshkini et al., 2018). These brains did show high MC cells numbers after exposure to 7.5 $\mathrm{mg} / \mathrm{L}$ up to $120 \mathrm{mg} / \mathrm{L}$ glyphosate in Roundup Ultra ${ }^{\mathrm{TM}}$, where even degranulation was observed (Eslava et al., 2007).

$\mathrm{MC}$ cells are produced from stem cells at hematopoietic organs, and do migrate via blood vessels to affected areas, where they do differentiate (Reite, Evensen, 2006; Sfacteria et al., 2015). It seems to be the case in our observations as the larger number of MC cells were detected nearby brain peripheral blood vessels. Arrival of larger number of MC cells to brain depends on Roundup Activo ${ }^{\mathrm{TM}}$ concentration, as more cells are observed after T4 exposure (Tab. 2), supporting the idea that Roundup Activo ${ }^{\mathrm{TM}}$ exposure may cause tissue damage and/or immune system activation in $P$. axelrodi brain.

Impact on physiological functions. The possibility that Roundup Activo ${ }^{\mathrm{TM}}$ could trigger an immune response, may lead to eventual brain physiological dysfunction. Reports on glyphosate effects in mammals range from alteration on mitochondrial dynamics, to increase in neuronal apoptosis, aromatase diminished activity, suppression of cytochrome P450, hippocampus oxidative stress, carcinogenesis and increase in blood brain barrier permeability. All these reports are useful in order to understand the effect of pure and commercial formulations of glyphosate, not only in mammals but in teleost fishes, due to the great similarity in many cellular, cerebral and metabolic processes (George et al., 2010; Gui et al., 2012; Mesnagea et al., 2012; Samsel, Seneff, 2013; Cattani et al., 2014).

The lateral (LD) and medial (MD) areas of C. auratus dorsal telencephalon are involved in recognition, learning and spatial orientation (Saito, Watanabe, 2004). These nuclei and Torus semicircularis do receive lateral line and preglomerular lateral nucleus sensitive and mechanoreceptor projections (Striedter, 1991). Dorsal telencephalon is innervated by olfactory projections from olfactory bulbs (Nieuwenhuys, Meek, 1990). Finally, dorsal telecephalon is reported to play a role in some mnemonic processes (Portavella et al., 2004).

Anterior preoptic parvocelular nucleus (PPa) and PDR ventral area periventricular hypothalamus (Hv) do play a neuroendocrine role, secreting isotocin an homologue of mammal oxytocin, involved in reproduction and behavior regulation. However, isotocin function is not clear yet (Gozdowska et al., 2006; Bernier et al., 2009). ArgininVasotocine, Cholecystokinin, Corticotrophin Releasing Factor, Galanin, Gastrin Releasing Peptide, Gonadotrophin Releasing Hormone, Growth Hormone Releasing Hormone, Neuropeptide Y, Somatostatin and Tyrotrophin Releasing Hormone are also released. These molecules are important in neuroendocrine and metabolism regulation, control of cardiovascular rhythm and blood pressure, release of gonadotrophin, corticotrophin, growth hormone and gastric acid, regulation adenohypophysary secretion, inhibition of growth hormone, gonadal maturation, activation of reproductive dynamics and osmoregulation (Bernier et al., 2009; Cerdá-Reverter, Canosa, 2009; Martins et al., 2014). An increased presence of MC cells in some neuronal nuclei, may trigger apoptosis events, by means of microgia activation as reported by Zhang et al. (2016), leading to diminished functions related to reproduction, adaptation and survival of $P$. axelrodi within the ecosystem.

$\mathrm{MC}$ cells were also found in PDR optic tectum $(\mathrm{TeO})$ and periventricular gray area (PGZ) peripheral blood vessels. These nuclei de play a role in food recognition, optomotor response, light intensity response, movement detection, color vision and integration of visual information (Marachlian et al., 2018). However, $\mathrm{TeO}$ also serves as an integration center for sensitive and mechanosensitive information coming from Torus semicircularis (TS) (Striedter, 1991). Feedback from $\mathrm{TeO}$ is important for Isthmi nucleus role in food recognition and predator avoidance. In addition, $\mathrm{TeO}$ do receives input from neuropeptide and $\mathrm{GnRH}$ neurons involved in reproductive stimuli, visual response to courtship and reproduction sites (Robles et al., 2011; Cooper et al., 2015; Umatani et al., 2015).

Torus lateralis (TLa) is considered a neuronal nucleus exclusive for Actinopterygian fishes (Butler, Hodos, 2005). 
It has been reported that Oncorhynchus mykiss TLa is involved in processing taste information (Folgueira et al., 2005). Paracheirodon axelrodi dwells on dark waters where any loss of visual or taste information may reduce feeding, depredator avoidance, shelter finding, and reproductive success.

The increase in the number of MC cells by exposure Roundup Active ${ }^{\mathrm{TM}}$ could also affect the physiological functions of other brain nuclei because the neuronal nuclei of the CNS have reciprocal connections with other nuclei. For example, it is known that AP is connected with nuclei as the periaqueductal gray area of the midbrain, the postrema of the caudal medulla, and the central gray area of the spinal cord (Nieuwenhuys et al., 1988). Paracheirodon axelrodi may be also used as an environmental biomarker of industrial and agriculture pollutants effect on aquatic ecosystems, as this species inhabit basins already used for extensive rice and palm oil plantations aspersed with Roundup Activo ${ }^{\mathrm{TM}}$. This fish may be used as a public health biomarker (Marchand et al., 2009; Barišića et al., 2015; Javed et al., 2015), as high glyphosate levels have been reported in waters of the Meta river basin (González et al., 2014), used for human consumption, which is a possible source of health problems.

In our study the use of Round Activo ${ }^{\mathrm{TM}}$ caused an increase in the $\mathrm{MC}$ cells number in the preoptic and posterior region area of $P$. axelrodi brain, the increments may affect directly CNS, causing deleterious performance in the species. In addition, this effect is dependent of the concentration, suggesting that glyphosate levels reported in nature may lead to central nervous system alterations, affecting $P$. axelrodi in its environment.

\section{Acknowledgment}

The authors are grateful to the Universidad Militar Nueva Granada for financing this research accepted in the project CIAS 1825.

\section{References}

American Veterinary Medical Association (AVMA). Guidelines for the euthanasia of animals: 2013 Edition. Schaumburg, IL: American Veterinary Medical Association; 2013.

Anjos DB, Anjos CR. Biología reproductiva e desenvolvimiento embrionario e larval do cardinal tetra, Paracheirodon axelrodi Shultz, 1956 (Characiformes: Characidae), em laboratório. Bol Inst Pesca. 2006; 32(2):151-60.

Barišić J, Dragun K, Ramani S, Marijić VF, Krasnići N, ČožRakovac R, Kostov V, Rebok K, Jordanova M. Evaluation of histopathological alterations in the gills of Vardar chub (Squalius vardarensis Karaman) as an indicator of river pollution. Ecotoxicol Environ Saf. 2015; 118:158-66. https:// doi.org/10.1016/j.ecoenv.2015.04.027

Bernier N, Van Der Kraak G, Farrell A, Brauner C, editors. Fish physiology: Fish neuroendocrinology. London: Academic Press; 2009.
Butler A, Hodos W. Comparative vertebrate neuroanatomy, evolution and adaptation. Hoboken, NJ: John Wiley \& Sons; 2005.

Cattaneo R, Clasen B, Loro VL, Menezes CC, Pretto A, Baldisserotto B, Santi A, Avila L. Toxicological responses of Cyprinus carpio exposed to a commercial formulation containing glyphosate. Bull Environ Contam Toxicol. 2011; 87(6):597-602. http://dx.doi.org/10.1007/s00128-011-0396-7

Cattani D, Cavalli VLLO, Rieg CEH, Domingues JT, Dal-Cim T, Tasca CI, Barreto Silva FRM, Zamoner A. Mechanisms underlying the neurotoxicity induced by glyphosate-based herbicide in immature rat hippocampus: Involvement of glutamate excitotoxicity. Toxicology. 2014; 320:34-45. http://dx.doi.org/10.1016/j.tox.2014.03.001

Cerdá-Reverter J, Canosa LF. Chapter 1: Neuroendocrine systems of the fish brain. Fish Physiol. 2009; 28:3-47. https://doi org/10.1016/S1546-5098(09)28001-0

Cooper SR, Emond MR, Duy PQ, Liebau BG, Wolman MA, Jontes JD. Protocadherins control the modular assembly of neuronal columns in the zebrafish optic tectum. J Cell Biol. 2015; 211(4):807-14. DOI:10.1083/jcb.201507108

Cox C. Problems plague the Environmental Protection Agency's pesticide registration activities. Glyphosate Factsheet. 2000; (91): 10 .

Dezfuli BS, Arrighi S, Domeneghini C, Bosi G. Immunohistochemical detection of neuromodulators in the intestine of Salmo trutta L. naturally infected with Cyathocephalus truncatus Pallas (Cestoda). J Fish Dis. 2000; 23(4):265-73. https://doi.org/10.1046/j.13652761.2000.00234.x

Eslava Mocha PR, Ramírez Duarte WF, Rondón Barragán IS. Sobre los efectos del glifosato y sus mezclas: Impacto sobre peces nativos. Villavicencio: Instituto de Acuicultura de los Llanos -IALL, Instituto de Investigaciones de la Orinoquia Colombiana -IIOC, Universidad de los Llanos; 2007.

Folgueira M, Anadón R, Yáñez J. Experimental study of the connections of the preglomerular nuclei and corpus mamillare in the rainbow trout, Oncorhynchus mykiss. Brain Res Bull. 2005; 66(4-6):361-64. https://doi.org/10.1016/j. brainresbull.2005.03.001

Fryer JN, L Maler. Hypophysiotropic neurons in the goldfish hypothalamus demonstrated by retrograde transport of horseradish peroxidase. Cell Tissue Res. 1981; 218(1):93102. Available from: https://link.springer.com/content/ pdf/10.1007\%2FBF00210094.pdf

Gaikwad A, Biju K, Muthal P, Saha S, Subhedar N. Role of neuropeptide $\mathrm{Y}$ in the regulation of gonadotropin releasing hormone system in the forebrain of Clarias batrachus (Linn.): inmunocytochemistry and high-performance liquid chromatography - electrospray ionization - mass spectometric analysis. Neuroscience. 2005; 133(1):267-79. https://doi. org/10.1016/j.neuroscience.2004.12.052

George J, Prasad S, Mahmood Z, Shukla Y. Studies on glyphosateinduced carcinogenicity in mouse skin: A proteomic approach. J Proteomics. 2010; 73(5):951-64. https://doi.org/10.1016/j. jprot.2009.12.008 
Glusczak L, Miron DS, Moraes BS, Simões RR, Schetinger MRC, Morsch VM, Loro VL. Acute effects of glyphosate herbicide on metabolic and enzymatic parameters of silver catfish (Rhamdia quelen). Comp Biochem Physiol. 2007; 146(4):519-24. https:// doi.org/10.1016/j.cbpc.2007.06.004

Gómez Ramirez E. Efecto de una presentación comercial de glifosato en alevinos de Cachama blanca (Piaractus brachypomus). [Master Dissertation]. Villavicencio: Universidad de los Llanos; 2013.

González J, Landines MA, Borbon J, Correal ML, Sanchez C, Rodriguez L. Evaluación de algunos marcadores de exposición a contaminantes en tres especies de bagres colombianos (Pisces: Siluriformes). Biota Colombiana. 2014; 15(S1):4049. Available from: http://revistas.humboldt.org.co/index.php/ biota/article/view/341/339

Gozdowska M, Kleszczyńska A, Sokołowska E, Kulczykowska E. Arginine vasotocin (AVT) and isotocin (IT) in fish brain: Diurnal and seasonal variations. Comp Biochem Physiol Biochem Mol Biol. 2006; 143(3):330-34.

Gui Y, Fan X, Wang H, Wang G, Chen S. Glyphosate induced cell death through apoptotic and autophagic mechanisms. Neurotoxicol Teratol. 2012; (34):344-49. https://doi. org/10.1016/j.cbpb.2005.12.004

Hued A, Oberhofer S, Bistoni M. Exposure to a commercial glyphosate formulation (Roundup ${ }^{\circledR}$ ) alters normal gill and liver histology and affects male sexual activity of Jenynsia multidentata (Anablepidae, Cyprinodontiformes). Arch Environ Contam Toxicol. 2012; 62(1):107-17. http://doi. org/10.1007/s00244-011-9686-7

Javed M, Usmani N, Ahmad I, Ahmad M. Studies on the oxidative stress and gill histopathology in Channa punctatus of the canal receiving heavy metal-loaded effluent of Kasimpur Thermal Power. Environ Monit Assess. 2015; 187(1):4179. http://doi. org/10.1007/s10661-014-4179-6

Kreutz LC, Barcellos LJG, Valle SF, Oliveira Silva T, Anziliero D, Santos ED, Pivato M, Zanatta R. Altered hematological and immunological parameters in silver catfish (Rhamdia quelen) following short term exposure to sublethal concentration of glyphosate. Fish Shellfish Immunol. 2011; 30(1):51-57. http:// doi.org/10.1016/j.fsi.2010.09.012

Marachlian E, Avitan L, Goodhill G, Sumbre G. Principles of functional circuit connectivity: Insights from spontaneous activity in the zebrafish optic tectum. Front Neural Circuits. 2018; 12:46. https://doi.org/10.3389/fncir.2018.00046

Marchand M, van Dyk J, Pieterse G, Barnhoorn I, Bornman M. Histopathological alterations in the liver of the sharptooth catfish Clarias gariepinus from polluted aquatic systems in South Africa. Environ Toxicol. 2009; 24(2):133-47. https:// doi.org/10.1002/tox.20397

Martins RST, Pinto PIS, Guerreiro PM, Zanuy S, Carrillo M, Canário AVM. Novel galanin receptors in teleost fish: Identification, expression and regulation by sex steroids. Gen Comp Endocrinol. 2014; 205:109-20.

Meshkini S, Rahimi-Arnaei M, Tafi A. The acute and chronic effect of Roundup herbicide on histopathology and enzymatic antioxidant system of Oncorhynchus mykiss. Int J Sci Environ Tecnol. 2018;1-10. https://doi.org/10.1007/s13762-018-2095-y
Mesnagea R, Bernayc B, Séralinia GE. Ethoxylated adjuvants of glyphosate-based herbicides are active principles of human cell toxicity. Toxicology. 2012; 313(2-3):122-28. https://doi. org/10.1016/j.tox.2012.09.006

Mulero I, Sepulcre M, Meseguer J, García-Ayala A, Mulero $\mathrm{V}$. Histamine is stored in mast cells of most evolutionarily advanced fish and regulates the fish inflammatory response. Proc Natl Acad Sci USA. 2007; 104(49):19434-39. https:// doi.org/10.1073/pnas.0704535104

Nelissen S, Lemmens E, Geurts N, Kramer P, Maurer M, Hendriks $\mathrm{J}$, Hendrix $\mathrm{S}$. The role of mast cells in neuroinflammation. Acta Neuropathol. 2013; 125(5):637-50. https://doi.org/10.1007/ s00401-013-1092-y

Nieuwenhuys R, Meek J. The telencephalon of sarcopterygian fishes in cerebral cortex. In: Jones EG, Peters A, editors. Comparative structure and evolution of cerebral cortex. Boston, MA: Springer; 1990.

Nieuwenhuys R, Veening JG, van Domburg P. Core and paracores: some new chemoarchitectural entities in the mammalian neuraxis. Acta Morphol Neerl Scand. 1988; 26(2-3):131-63.

O'Connell LA, Fontenot MR, Hofmann HA. Neurochemical profiling of dopaminergic neurons in the forebrain of a cichlid fish, Astatotilapia burtoni. J Chem Neuroanat. 2013; 47:10615. https://doi.org/10.1016/j.jchemneu.2012.12.007

Obando-Bulla MJ, Gómez-Rodriguez E, Tovar-Bohorquez MO, Rincón L, Caldas-Martínez ML, Hurtado-Giraldo H. Estudio morfométrico y anatómico del cerebro del pez neón cardenal, Paracheirodon axelrodi (Characiformes: Characidae). Actual Biol. 2013; 35(98):45-61. Available from: http://www.scielo. org.co/pdf/acbi/v35n98/v35n98a5.pdf

Portavella M, Torres B, Salas C. Avoidance response in goldfish: emotional and temporal involvement of medial and lateral telencephalic pallium. J Neurosci. 2004; 24(9):2335-42. https://doi.org/10.1523/JNEUROSCI.4930-03.2004

Ramírez-Duarte W, Rondón-Barragan ISR, Eslava-Mocha PR. Efectos del glifosato (GP) con énfasis en organismos acuáticos (revisión literatura). Orinoquia. 2003; 7(1-2):70100. https://doi.org/10.22579/20112629.270

Ramírez-Duarte W, Rondón-Barragan IRS, Eslava-Mocha PR. Acute toxicity and histopathological alterations of Roundup ${ }^{\circledR}$ herbicide on "Cachama blanca" (Piaractus brachypomus). Pesq Vet Bras. 2008; 28(11):547-54. http:// dx.doi.org/10.1590/S0100-736X2008001100002

Reite OB, Evensen Ø. Inflammatory cells of teleostean fish: A review focusing on mast cells/eosinophilic granule cells and rodlet cells. Fish Shellfish Immunol. 2006; 20(2):192-208. https://doi.org/10.1016/j.fsi.2005.01.012

Rincón L, Obando MJ, Tovar MO, Pandolfi M, Hurtado H. Topological and histological description of preoptic area and hypothalamus in cardinal tetra Paracheirodon axelrodi (Characiformes: Characidae). Neotrop Ichthyol. 2017; 15(1):e160145. 10.1590/1982-0224-20160145

Robles E, Smith SJ, Baier H. Characterization of genetically targeted neuron types in the zebrafish optic tectum. Front Neural Circuits. 2011. https://doi.org/10.3389/ fncir.2011.00001 
Glyphosate effects in brain of Paracheirodon axelrodi

Saito K, Watanabe S. Spatial learning deficits after the development of dorsomedial telencephalon lesions in goldfish. Neuroreport. 2004; 15(18):2695-99.

Samsel A, Seneff S. Glyphosate's suppression of cytochrome p450 enzymes and amino acid biosynthesis by the gut microbiome: Pathways to modern diseases. Entropy. 2013; 15(4):1416-63. https://doi.org/10.3390/e15041416

Sandrini JZ, Rola RC, Lopes FM, Buffon HF, Freitas MM, Martins CMG, Rosa CE. Effects of glyphosate on cholinesterase activity of the mussel Perna and the fish Danio rerio and Jenynsia multidentata: In vitro studies. Aquat Toxicol. 2013; 130 131:171-73. https://doi.org/10.1016/j.aquatox.2013.01.006

Sinhorin VDG, Sinhorin AP, Teixeira JMS, Miléski KML, Hansen PC, Moreira PSA, KawashitaN H, Baviera AM, Loro VL. Effects of the acute exposition to glyphosate-based herbicide on oxidative stress parameters and antioxidant responses in a hybrid Amazon fish surubim (Pseudoplatystoma sp). Ecotoxicol Environ Saf. 2014; 106:181-87.

Sfacteria A, Brines M, Blank U. The mast cell plays a central role in the immune system of teleost fish. Mol Immunol. 2015; 63(1):3-8. https://doi.org/10.1016/j.molimm.2014.02.007

Striedter GF. Auditory, electrosensory, and mechanosensory lateral line pathways through the forebrain in channel catfishes. J Comp Neurol. 1991; 312(2):311-31. https://doi.org/10.1002/ cne. 903120213

Theoharides TC, Cochrane DE. Critical role of mast cells in inflammatory diseases and the effect of acute stress. J Neuroimmunol. 2004; 146(1-2):1-12. https://doi. org/10.1016/j.jneuroim.2003.10.041
Umatani C, Misu R, Oishi S, Yamaguchi K, Abe H, Oka Y. GnRH suppresses excitability of visual processing neurons in the optic tectum. J Neurophysiol. 2015; 114(5):2775-84. https:// doi.org/10.1152/jn.00710.2015

United Nations Office on Drugs and Crime (UNODC). Monitores de cultivos ilícitos de coca. Bogota: United Nations Office on Drugs and Crime; Gobierno de Colombia; 2014.

Wilhelm M, Silver R, Silverman A. Central nervous system neurons acquire mast cell products via transgranulation. Eur J Neurosci. 2005; 22(9):2238-48. https://doi.org/10.1111/ j.1460-9568.2005.04429.x

World Health Organization (WHO). Environmental health criteria, Publication 159: Glyphosate. Geneva, Switzerland: INCHEM; 1994. Available from: http://www.inchem.org/documents/ehc/ ehc/ehc159.htm

Wullimann MF, Rupp B, Relchert H. Neuroanatomy of the zebrafish brain: a topological atlas. Basel: Birkhauser Verlag; 1996.

Zhang X, Dong H, Li N, Zhang S, Sun J, Zhang Sh, Qian Y. Activated brain mast cells contribute to postoperative cognitive dysfunction by evoking microglia activation and neuronal apoptosis. J Neuroinflammation. 2016; 31(13):127. https://doi. org/10.1186/s12974-016-0592-9

Submitted February 25, 2019

Accepted September 23, 2019 by Bernardo Baldisserotto 